\title{
The genus Crataegus: chemical and pharmacological perspectives
}

\author{
Dinesh Kumar, ${ }^{*}, 1$ Vikrant Arya, ${ }^{2}$ Zulfiqar Ali Bhat, ${ }^{1}$ Nisar Ahmad \\ Khan, ${ }^{1}$ Deo Nandan Prasad ${ }^{3}$
}

${ }^{I}$ Department of Pharmaceutical Sciences, University of Kashmir, India,

${ }^{2}$ ASBASJSM College of Pharmacy, Bela Ropar, Punjab, India,

${ }^{3}$ Shivalik College of Pharmacy, Naya-Nangal, Punjab, India.

\begin{abstract}
Traditional drugs have become a subject of world importance, with both medicinal and economical implications. A regular and widespread use of herbs throughout the world has increased serious concerns over their quality, safety and efficacy. Thus, a proper scientific evidence or assessment has become the criteria for acceptance of traditional health claims. Plants of the genus Crataegus, Rosaceae, are widely distributed and have long been used in folk medicine for the treatment of various ailments such as heart (cardiovascular disorders), central nervous system, immune system, eyes, reproductive system, liver, kidney etc. It also exhibits wide range of cytotoxic, gastroprotective, anti-inflammatory, anti-HIV and antimicrobial activities. Phytochemicals like oligomeric procyanidins, flavonoids, triterpenes, polysaccharides, catecholamines have been identified in the genus and many of these have been evaluated for biological activities. This review presents comprehensive information on the chemistry and pharmacology of the genus together with the traditional uses of many of its plants. In addition, this review discusses the clinical trials and regulatory status of various Crataegus plants along with the scope for future research in this aspect.
\end{abstract}

Received 9 Sep 2011

Accepted 9 Apr 2012

Available online 16 Aug 2012

Keywords: Crataegus

flavonoids

hawthorn

maloideae/Rosaceae thorny bush

ISSN 0102-695X http://dx.doi.org/10.1590/S0102$695 \times 2012005000094$

\section{Introduction}

The genus name Crataegus, Rosaceae, is derived from a Greek word kratos meaning hardness of wood (Verma et al., 2007). Crataegus comprises of a complex group of trees and shrubs, native to Northern temperate zones, mostly between latitudes $30^{\circ}$ and $50^{\circ}$ N. Crataegus belongs to the subfamily Maloideae in the Rosaceae, a natural group of complex genera with the ability to interbreed freely (hybridize). They all possess the basal chromosome number of 17 . In general they do not form large trees or exist as canopy dominants in forests. Some species are decidedly shrubby, whereas others can grow to heights of $12 \mathrm{~m}$, although most species can attain tree-sized proportions. Hawthorn refers to the plant Crataegus and is widely distributed throughout the Northern temperate region of the world with approximately 280 species (Robertson, 1974; Huang et al., 2004; Donmez, 2004). Crataegus synonyms and common names in several European languages come from its physical characteristics of being a thorny bush, commonly used as hedging. The word 'haw' is an old English word for "hedge". The German hagedorn, meaning "hedgethorn", reveals that from a very early period, they were using Crataegus as hedging to divide their land into plots. The name 'may' is associated with the month in which the plant traditionally blossoms in England. Whitethorn Crataegus indicates the whiteness of its bark and the name 'Quickset' comes from its ability to establish itself rapidly. To appease their hunger before breakfast, farmers used to nibble on the flowers and leaves, hence the names Bread and Butter Tree or Bread and Cheese Tree.

\section{General description}

Leaves of the most species of Crataegus have two leafy bracts, their stalks meet the twig. Leaves are $15 \mathrm{~mm}-5 \mathrm{~cm}$ long, glabrous, broad-ovate or obovate and have toothed margins with three to seven lobes. The flowers grow in clusters of 5-12 with colour ranges from white to pink, pink to red. They contain both male and female sexes and are mostly fertilized by insects, which are attracted by the perfume released by the flowers. Red fruits are also known as Pixie Pears, Cuckoo's Beads and Chucky Cheese in some areas in England. These ovoid false fruits are known as Hawthorn berries which are greenish-red when they first appear, gradually turning bright red and then a deep red. They have meaty white flesh containing one or two stony fruits (WHO, 2003; Huang et al., 2004). 


\section{Distribution}

These small sized trees are grown as a hedge plant in Europe. Found mostly in temperate areas including countries like North Africa, Western Asia, India, China and North America. In the 1800s, British settlers introduced it into Tasmania and other parts of Australia as a hedge plant and it now runs wild in Victoria, Tasmania, the Adelaide Hills and the tablelands of New South Wales. Crataegus is an aggressive settler that i.e. tenacious and difficult to remove; it has been declared a noxious weed in many Australian states. In India, it is found in the temperate Himalayas, Kashmir and Himachal Pradesh, at an altitude of 1800-3000 m (Verma et al., 2007).

\section{Traditional use}

Crataegus species (hawthorn) have been used traditionally since ancient times. Furthermore, it has been proposed that its antioxidant constituents account for its beneficial therapeutic effects. A decoction of leaves and unripe fruits from Crataegus aronia is used to treat cardiovascular diseases, cancer, diabetes and sexual weakness in Arabian traditional medicine system (Miller, 1998; Ju, 2005). In Mexico, diabetes is treated with hawthorn extracts. Such treatment may be of considerable benefit especially during the early stages of the illness (Rigelsky \& Sweet, 2002). In folk medicine, several hawthorn species are mainly used for treating cardiovascular diseases including Crataegus pinntiflda (Chinese hawthorn), C. pubesens (Mexican hawthorn), C. cuneata (Japanese hawthorn), C. laevigata and C. monogyna (Europe), C. oxycantha and C. aronica (Middle East), C. phaenopyrum (American hawtrorn) and C. ambigua (Russian hawthorn) (Khalil et al., 2008; Ljubuncic et al., 2005). Hawthorn (C. pinnatifida) is an edible fruit used in traditional Chinese medicine to lower plasma lipids (Lin et al., 2009). Dried fruits of C. pinnatifida have been used traditionally as oriental medicine and local soft drink material in Taiwan (Kao et al., 2007).

\section{Chemistry}

The leaves, flowers and berries of hawthorn contain a variety of bioflavonoid-like complexes that appear to be primarily responsible for the cardiac actions of the plant. Biflavonoids found in hawthorn plant include oligomeric procyanidins (OPC), vitexin, quercetin, and hyperoside. The action of these compounds on the cardiovascular system has led to the development of leaf and flower extracts, which are widely used in Europe. Other chemical constituents includes vitamin C, saponins, tannins, cardiotonic amines (phenylethylamine, tyramine, isobutylamine, $O$-methoxy phenylethylamine, choline and acetylcholine), purine derivatives (adenosine, adenine, guanine, caffeic acid, amygdalin), triterpene acids ursolic acid (Verma et al., 2007). Various reported chemical constituents from Genus Crataegus have been mentioned in Chart 1.<smiles>Oc1cc(O)c2c(c1)O[C@H](c1ccc(O)c(O)c1)[C@H](O)[C@H]2c1c(O)cc(O)c2c1O[C@H](c1ccc(O)c(O)c1)[C@H](O)C2</smiles>

1<smiles>O=C(/C=C/c1ccc(O)c(O)c1)OC1C[C@](O)(C(=O)O)C[C@H](O)[C@H]1O</smiles>

5<smiles>[R]O[C@@H]1[C@@H](O)[C@@H](O)[C@H](c2c(O)cc(O)c3c(=O)cc(-c4ccc(O)cc4)oc23)O[C@@H]1CO</smiles>

$2 \mathrm{R}=\mathrm{H}$

$3 \mathrm{R}=2$ "-O-rhamnose<smiles>[R20]C[C@H]1O[C@@]2(Cc3c(cc(O)c4c(=O)cc(-c5ccc(O)cc5)oc34)O2)[C@H](O)[C@@H]1O</smiles>

$6 \mathrm{R}=\mathrm{H}$

$7 \mathrm{R}=\mathrm{Ac}$<smiles>O=c1c(OC(O)C2OC3C(O)C(O)C(O)C(O)C3O2)c(-c2ccc(O)c(O)c2)oc2cc(O)cc(O)c12</smiles>

4<smiles>CC1(C)CCC2(C(=O)O)CC[C@H]3C(=CCC4[C@@]3(C)CC[C@H]3C(C)(C)[C@@H](O)CC[C@]43C)C2C1</smiles>

8 


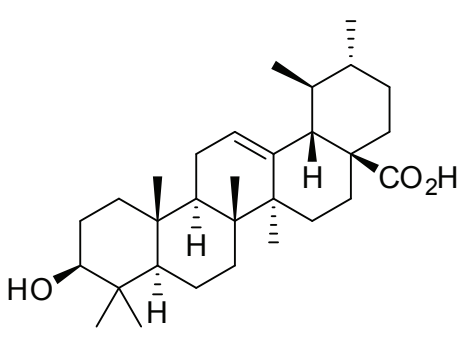

9<smiles>CC(=O)OC[C@H]1O[C@@]2(Cc3c(cc(O)c4c(=O)cc(-c5ccc(O)cc5)oc34)O2)[C@H](O)[C@@H]1O</smiles>

13<smiles>O=C1c2c(O)cc(O)cc2O[C@H](c2ccc(O)c(O)c2)[C@@H]1O</smiles>

16<smiles>O=C(O)C=Cc1ccc(O)cc1</smiles>

19<smiles>[R]OC[C@H]1O[C@@]2(Cc3c(cc(O)c4c(=O)cc(-c5ccc(O)cc5)oc34)O2)[C@H](O)[C@@H]1O</smiles>

$10 \mathrm{R}=\mathrm{H}$

$11 \mathrm{R}=\mathrm{Ac}$<smiles>COc1ccc([C@H]2CC(=O)c3c(O)cc(O)cc3O2)cc1O</smiles>

14<smiles>O=C1C[C@H](c2ccc(O)cc2)Oc2cc(O)cc(O)c21</smiles>

17<smiles>[R]C1C(=O)c2c(O)cc(O)cc2OC1c1ccc(O)c(O)c1</smiles>

$20 \mathrm{R}=\mathrm{H}$

$21 \mathrm{R}=$ Rham-Glu<smiles>CC(C)(C)OC[C@H]1O[C@@]2(Cc3c(cc(O)c4c(=O)cc(-c5ccc(O)cc5)oc34)O2)[C@H](O)[C@@H]1O</smiles>

12<smiles>O=c1cc(-c2ccc(O)cc2)oc2cc(O)cc(O)c12</smiles>

15

18

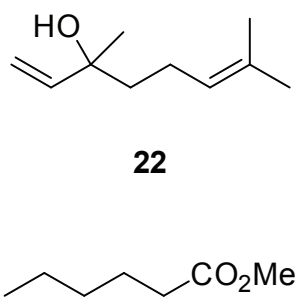

23

\section{Pharmacological activities}

Crataegus species possesses immense medicinal applications, but a few species have been screened for their biological activities. The experimental results have shown a wide spectrum of such effects; some of them have been discussed and summarized in Chart 2. Crataegus may improve coronary artery blood flow and the contractions of the heart muscle, hence used widely in cardiovascular disorders like arrhythmia, myocardial infarction, congestive heart failure (Long et al., 2006; Degenring et al., 2003; Tadic et al., 2008; Jayalakshmi et al., 2006; Garjani et al., 2000). Crataegus extracts also prevents elimination of plasma lipids such as total cholesterol, triacylglycerides and LDL and VLDL fractions (Ljubuncic et al, 2006; Andrade-Cetto \& Heinrich, 2005). Crataegus may be employed as antiinflammatory, gastro-protective, antimicrobial agent and used as hepatoprotective agent (Tadic et al., 2008; Kao et al 2005). It is also mildly inhibits angiotensin converting enzyme (ACE) and reduce production of the potent blood vessel-constricting substance angiotensin II, hence act as hypotensive and diuretic (Schroder et al., 2003). It mildly 
Chart 1. Bioactive compounds isolated from genus Crataegus.

\begin{tabular}{|c|c|c|c|}
\hline Species & Chemical constituents & Compound name & References \\
\hline C. monogyna & $\begin{array}{l}\text { Phenolic compounds, di- } C \text { - } \\
\text { glycosides }\end{array}$ & $\begin{array}{l}\text { proanthocyanidin (1), vitexine-2- } O \text {-rhamnoside } \\
\text { (3), hyperoside (4), anthocyanin, chlorogenic acid } \\
\text { (5), epicatechin, apigenin-6,8-di- } C \text {-glycosides }\end{array}$ & $\begin{array}{l}\text { Orhan et al., 2007; Bahorun, } \\
\text { et al., 2003; Nikolov \& } \\
\text { Vodenicharov, } 2003\end{array}$ \\
\hline C. aronia & Phenolics & $\begin{array}{l}\text { oligomeric proanthocyanidin, flavanoids } \\
\text { (vitexine-2- } O \text {-rhamnoside }(3) \text {, hyperoside (4)) }\end{array}$ & Orhan et al., 2007 \\
\hline C.pseudoheterophylla & Phenolics & $\begin{array}{l}\text { oligomeric proanthocyanidin, flavanoids } \\
\text { (vitexine-2- } O \text {-rhamnoside }(3) \text {, hyperoside (4)) }\end{array}$ & Orhan et al., 2007 \\
\hline C. pinnatifida & $\begin{array}{l}\text { Flavanoid glycoside, } \\
\text { furanoflavonoids, triterpenic acid, } \\
\text { flavonoid ketohexosefuranosides, } \\
\text { biphenyl glucoside }\end{array}$ & $\begin{array}{l}\text { pinnatifin C (6), pinnatifin D (7), oleanolic acid } \\
(\mathbf{8}) \text {, ursolic acid }(\mathbf{9}) \text {, pinnatifinoside A }(\mathbf{1 0}), \\
\text { pinnatifinoside B }(\mathbf{1 1}) \text {, pinnatifinoside C (12), } \\
\text { pinnatifinoside D (13), shanyenoside A }\left(5,4^{\prime}-\right. \\
\text { dimethoxy-biphenyl-4-ol-3-O- } \beta \text {-D-glucoside })\end{array}$ & $\begin{array}{l}\text { Zhang et al., 2000; Maurya \& } \\
\text { Yadav, 2005; Lin et al., 2009; } \\
\text { Chen et al., 2008; Zhang \& Xu, } \\
2001\end{array}$ \\
\hline C. laevigata & Oligomeric procyanidins & $\begin{array}{l}\text { epicatechin- }(4 \beta \rightarrow 8) \text {-epicatechin- }(4 \beta \rightarrow 6) \text { - } \\
\text { epicatechin, pentamer of }(-) \text {-epicatechin units } \\
\text { linked through } C-4 \beta / C-8 \text { bonds }\end{array}$ & Svedstrom et al., 2002 \\
\hline C. microphylla & Flavanoids & $\begin{array}{l}\text { hesperetin (14), apigenin (15), vitexin (2), } \\
\text { vitexin-4'-O-rhamnoside }\end{array}$ & Melikoglu et al., 2004 \\
\hline Crataegi folium & Phenolics & $\begin{array}{l}\text { catechin (16), naringenin (17), gallic acid (18), } \\
\text { coumaric acid (19), caffeic acid }\end{array}$ & Demiray et al., 2009 \\
\hline C. scabrifolia & Carbohydrates & sugars, acids, sugar alcohols & Liu et al., 2010 \\
\hline C. davisii & Flavanoids & $\begin{array}{l}\text { hyperoside (4), vitexin-2-O-rhamnoside (3), } \\
\text { vitexin-4'-O-rhamnoside, rutin (20), quercetin } \\
\text { (21) }\end{array}$ & Sozer et al., 2006 \\
\hline C. macrocarpa & Flavanoids & $\begin{array}{l}\text { eriodictyol-7-glucuronide, luteolin-7-O- } \\
\text { glucuronide }\end{array}$ & Ringl et al., 2007 \\
\hline C. pentaegyna & Phenolics & flavanoids & $\begin{array}{l}\text { Ebrahimzadeh \& Bahramian, } \\
2009\end{array}$ \\
\hline $\begin{array}{l}\text { C. opaca, } \\
\text { C. aestivalis, } \\
\text { C. rufula }\end{array}$ & Volatile components & $\begin{array}{l}\text { linalool (22), hexanal, butyl hexanoate, pentyl } \\
\text { hexanoate, methyl hexanoate (23) }\end{array}$ & Horvat \& Chapman, 2007 \\
\hline C. meyeri & Carbohydrates & polysaccharides & Kuliev \& Poletaeva, 1984 \\
\hline C. curvisepala & Flavanoids & cratenacin & Batyuk, 1996 \\
\hline C. orientalis & Carbohydrates & polysaccharides & Kuliev \& Poletaeva, 1983 \\
\hline C. turkestanica & Phospholipids & $\begin{array}{l}\text { phosphatidylethanolamine, phosphatidylcholine, } \\
\text { phosphatidylinositol }\end{array}$ & Gazizov \& Glushenkova 1996 \\
\hline $\begin{array}{l}\text { C. jackii, } \\
\text { C. robesoniana, } \\
\text { C. flabellata }\end{array}$ & Essential oils & $\begin{array}{l}\text { decane, linalool (22), syringaldehyde B, } \\
\text { syringaldehyde } \mathrm{C} \text {, syringaldehyde } \mathrm{D}, \\
\text { caryophylleneoxide, squalene, eicosane, }\end{array}$ & Kovaleva et al., 2009 \\
\hline C. oxyacatha & $\begin{array}{l}\text { Flavanoids, Oligomeric } \\
\text { procyanidins, Cardiotonic amines, } \\
\text { triterpenes, Purine derivatives }\end{array}$ & $\begin{array}{l}\text { heptahydroxyflavan glycoside, flavan polymers, } \\
\text { quercetin }(\mathbf{2 1}) \text {, hyperoside }(\mathbf{4}) \text {, rutin }(\mathbf{2 0}) \text {, } \\
\text { flavonoglycosyls, vitexin-4'-rhamnoside, } \\
\text { epicatechol, tyramine, isobutylamine, } O \text {-methoxy } \\
\text { phenylethylamine, ursolic acid (9), oleanolic acid } \\
(\mathbf{8}) \text {, crategolic acid, adenosine, adenine, guanine, } \\
\text { caffeic acid, polyphenols }\end{array}$ & $\begin{array}{l}\text { Bersin et al., 1955; Rewerski \& } \\
\text { Lewak, 1967; Verma et al, 2007; } \\
\text { Aneta \& Oszmianski, } 2007\end{array}$ \\
\hline C. sanguine & Flavanoid & acetylvitexin & $\begin{array}{l}\text { Kashnikova et al., 1984; } \\
\text { Kashnikova, } 1984\end{array}$ \\
\hline $\begin{array}{l}\text { C. azarolus var. eu- } \\
\text { azarolus, C. aronia }\end{array}$ & Polyphenols & $\begin{array}{l}\text { chlorogenic acid (5), hyperoside (4), quercetin } \\
(\mathbf{2 1}) \text {, rutin (20), spiraeoside, epicatechin }\end{array}$ & Bahri-Sahloul et al., 2009 \\
\hline C. sinaica & Polyphenols & anthocyanin & Maharik et al., 2009 \\
\hline $\begin{array}{l}\text { Crataegi folium cum } \\
\text { flore }\end{array}$ & Flavanoids, flavone rotamers & $\begin{array}{l}\text { flavonol 8-methoxykaempferol 3-O-(6"-malonyl- } \\
\text { beta glucopyranoside }\end{array}$ & $\begin{array}{l}\text { Amanzadeh et al., 2007; Rayyan } \\
\text { et al, } 2005\end{array}$ \\
\hline C. cuneata & Triterpenoid & cuneataol & Ikeda et al., 1999 \\
\hline C. flava & Eudesmanolide & $\begin{array}{l}1 \beta, 9 \alpha \text {-dihydroxyeudesm-3-en- } 5 \beta, 6 \alpha, 7 \alpha, 11 \alpha H \text { - } \\
12,6 \text {-olide }\end{array}$ & Ahmed et al., 2001 \\
\hline
\end{tabular}




\begin{tabular}{ll}
\hline C. macrocarpa & Flavanoids \\
C. pubescens & Polymer of sugar acids \\
C. maximowiczii & Flavanoids
\end{tabular}

lower blood pressure in some individuals with high blood pressure but should not be thought of as a substitute for cardiac medications for this condition. Crataegus showed high antioxidant and immunostimulating activity (Li et al., 2009). Crataegus is also employed in CNS disorders like anxiety and mild depression (Hanus et al., 2004).

\section{Antihypertensive activity}

It was observed that the hyperoside fraction and aqueous extract of Crataegus tanacetifolia prevented L-NAME-induced hypertension in rats and had beneficial effects on the cardiovascular system (Kocyildiz et al., 2006). In another study, the camphor-crataegus berry combination (CCC) drops decreased the orthostatic fall in blood pressure (Belz et al., 2002).

\section{Anti-arrythmic activity}

Crataegus oxyacantha extract was compared with other known cardioactive drug like ouabain, epinephrine, milrinone and propranolol for anti-arrthmic potential. Extract showed a unique activity profile as compared to conventional cardiac drugs. Its extract appeared to be capable of inducing rhythmicity in quiescent cardiomyocytes and showed antiarrhythmic activity. The commercial hawthorn preparations also exhibit similar chronotropic activities. Its extract also showed negative chronotropic effects and does not cause $\beta$-adrenergic receptor blockade (Long et al., 2006).

\section{Myocardial infarction}

Crataegus extract (hawthorn) possess positive inotropic effect of amines such as phenethylamine, $O$-methoxyphenethylamine and tyramine. These amines were responsible for in vitro activity of Crataegus extracts on the guinea pig papillary muscle (Wagner \& Grevel, 1982) and it also raised intracellular calcium thus prolongs the action potential, which supports for its inotropic activity (Kocyildiz et al., 2006). In another study, alcoholic extract of Crataegus oxycantha (AEC) was found to maintain mitochondrial antioxidant status, decreased Kreb's cycle enzymes induced by isoproterenol in rat heart and prevented mitochondrial lipid peroxidative damage (Jayalakshmi et al., 2006).

Myocardial ischaemia
Hawthorn used as anti-atheromatous and coronarodilatating agent (Petkov, 1979). The hydroalcoholic extract of Crataegus meyeri $(1 \mathrm{mg} / \mathrm{kg} /$ min) infused to rats, resulted in a significant decrease in the total number of ventricular ectopic beats. Chloroform extract of Crataegus meyeri ( $1 \mathrm{mg} / \mathrm{kg} / \mathrm{min})$ infused also reduced the total number of ventricular ectopic beats but this reduction was due to the decrease of single extra systoles. Hydroalcoholic and ethyl acetate infused extracts significantly reduced the time spent for ventricular fibrillation. During the extract infusion there were no significant changes in the heart rate and blood pressure but bolus injection of all the extracts significantly reduced the blood pressure. Thus, the extracts of Crataegus meyeri may possess active principles which have a hypotensive and antiarrhythmic potential on ischaemic myocardium (Garjani et al., 2000). In another study Crataegus oxycantha extract was evaluated to prevent ischemia-reperfusion injury in an in vivo rat model of acute myocardial infarction. Crataegus extract (100 $\mathrm{mg} / \mathrm{kg}$ body weight) showed a significant decrease in creatine kinase activity and infarct size. At the molecular level, Crataegus administration resulted in a significant attenuation of phosphatase and tensin homolog, deleted on chromosome, up regulation of phospho-Akt and c-Raf levels in the heart and this suggested that Crataegus extract attenuated apoptotic incidence in the experimental myocardial ischemia-reperfusion model by regulating Akt and hypoxia-inducible factor (HIF-1) signalling pathways (Garjani et al., 2000).

\section{Congestive heart failure}

Crataegus is used widely in cardiology (Blesken, 1992). The standardised extract of fresh berries of Crataegus oxyacantha L. and C. monogyna Jacq. $\left(\right.$ Crataegisan $\left.{ }^{\circledR}\right)$ have shown potent effect in patients with cardiac failure NYHA class II. A total of 143 patients were treated with three times 30 drops of the extract or placebo orally administered for eight weeks. The results showed a significant improvement in their heart failure condition under long term therapy with the standardised extract of fresh Crataegus berries (Degenring et al., 2003). In another study, the Crataegus extract WS 1442 inhibited balloon catheter-induced intimal hyperplasia in the rat carotid artery by directly influencing plateletderived growth factor receptor (PDGFR-beta). The results indicated that the polyphenols might be responsible 
Chart 2. Pharmacological activities of Crataegus species.

\begin{tabular}{|c|c|c|c|}
\hline Species & Part/extract & Pharmacological activities & References \\
\hline C. oxyacantha & $\begin{array}{l}\text { Leaves, stem, dried berries } \\
\text { (alcoholic) }\end{array}$ & $\begin{array}{l}\text { Negative chronotropic effect, cardiotonic, } \\
\text { congestive heart failure treatment; free- } \\
\text { radical-scavenging, anti-inflammatory, } \\
\text { gastroprotective and antimicrobial } \\
\text { activities; myocardial infarction } \\
\text { treatment, antioxidant, inhibition of } \\
\text { thromboxane } \mathrm{A}_{2}\end{array}$ & $\begin{array}{l}\text { Long et al., 2006; Degenring } \\
\text { et al., 2003; Tadic et al. 2008; } \\
\text { Jayalakshmi et al., 2006; Anna } \\
\text { et al., } 2007\end{array}$ \\
\hline C. aronia & Berries, leaves, flowers (aqueous) & Antioxidant; antidiabetic & $\begin{array}{l}\text { Ljubuncic et al. 2005; } \\
\text { Ljubuncic et al., } 2006\end{array}$ \\
\hline C. laevigata & $\begin{array}{l}\text { Berries (dichloromethane and } \\
\text { methanol) }\end{array}$ & Antioxidant & Kirakosyan et al., 2003 \\
\hline C. monogyna & $\begin{array}{l}\text { Flowers bearing branches, fruits } \\
\text { (dichloromethane, ethanol) }\end{array}$ & Antioxidant, negative chronotropic effect & $\begin{array}{l}\text { Kirakosyan et al., 2003; } \\
\text { Degenring et al., } 2003\end{array}$ \\
\hline C. pinnatifida & $\begin{array}{l}\text { Berries, fruits, leaves } \\
\text { (dichloromethane, ethylacetate, } \\
\text { acetone, ethanol, heptane, hot } \\
\text { water) }\end{array}$ & $\begin{array}{l}\text { Lipid-lowering, anti-inflammatory, } \\
\text { against oxidative stress, anticataract } \\
\text { potential, immunobiological; } \\
\text { hepatoprotective, cytotoxic }\end{array}$ & $\begin{array}{l}\text { Lin et al., 2009; Wang et al., } \\
\text { 2011; Li et al., 2009; Kao et } \\
\text { al., } 2005\end{array}$ \\
\hline C. meyeri & Flower heads (petroleum ether) & Myocardial ischaemia & Garjani et al., 2000 \\
\hline Crataegi folium & Leaves (acetone, methanol, water) & Antioxidant & Demiray et al., 2009 \\
\hline C. mexicana & Root infusion; leaves (hexane) & $\begin{array}{l}\text { Hypoglycaemic. relaxant effect on guinea } \\
\text { pig tracheal smooth muscle }\end{array}$ & $\begin{array}{l}\text { Andrade-Cetto \& Heinrich, } \\
\text { 2005; Arrieta et al., } 2010\end{array}$ \\
\hline $\begin{array}{l}\text { C. aronia, C. monogyna, } \\
\text { C. pseudoheterophylla }\end{array}$ & Leaves, fruits (ethanolic) & $\begin{array}{l}\text { Antibacterial, antifungal, antiviral, } \\
\text { antidiabetic }\end{array}$ & Orhan, et al., 2007 \\
\hline C. tanacetifolia & Leaves (water) & Hypotensive, antimicrobial & Kocyildiz et al., 2006 \\
\hline C. pentaegyna & Fruits (methanolic, aqueous) & Antioxidant & $\begin{array}{l}\text { Ebrahimzadeh \& Bahramian, } \\
2009\end{array}$ \\
\hline C. microphylla & Fruits (methanolic) & Radioprotective & Hosseinimehr et al., 2009. \\
\hline C. sinaica & $\begin{array}{l}\text { Fruits, leaves (acetone, ethyl } \\
\text { acetate, butanol, water) }\end{array}$ & $\begin{array}{l}\text { Antiviral, including anti-HIV, antioxidant, } \\
\text { anti-complementary }\end{array}$ & $\begin{array}{l}\text { Shahat et al., 1996; Shahat et } \\
\text { al., } 1998\end{array}$ \\
\hline Crataegus spp. & Fruits, leaves & Diuretic/ACE inhibitor & Schroder et al., 2003 \\
\hline C. azarolus var. eu- azarolus & Flower (ethyl acetate) & $\begin{array}{l}\text { Antioxidant, treatment of ischaemic heart } \\
\text { failure }\end{array}$ & Bahri-Sahloul et al., 2009; \\
\hline C. bornmulleri & Fruits (ethyl acetate) & Antimicrobial & Guven et al., 2006. \\
\hline C. cuneata & Roots (water decoction) & Improve sperm motility & Hu \& Xiong 2006. \\
\hline C. orientalis & Leaves (ethanolic) & Antithrombotic & Arslan et al., 2010. \\
\hline
\end{tabular}

to ameliorate post-angioplasty restenosis and prevent balloon catheter-induced intimal hyperplasia (Furst et al., 2010).

\section{Antihyperlipdemic activity}

Crataegus pinnatifida is an edible fruit used in traditional Chinese medicine to lower plasma lipids. A study was conducted on hawthorn fruits for investigation of its lipid-lowering property. Hawthorn powder extracts inhibited acylCoA: cholesterol acyltransferase (ACAT) activity in Caco- 2 cells. The triterpenic acids like oleanolic acid and ursolic acid in the extracts were responsible for its cholesterol lowering effects and it was also found that plant sterol esters provide an additive effect in combination to triterpenic acids (Lin et al., 2009). In another study aqueous extract of Crataegus aronica fruits exerted hypolipidaemic potential which was determined on rabbits fed with an atherogenic diet. Hawthorn fed rabbits showed inhibition of intestinal acylCoA: cholesterol acyltransferase without effecting the activities of hepatic 3-hydroxy-3-methyl glutaryl coenzyme A reductase (HMG-CoA-R) or cholesterol $7 \alpha-$ hydroxylase which explain its hypolipidaemic potential (Khalil et al., 2008).

\section{Antioxidant activity}

Crataegus laevigata and $C$. monogyna (hawthorn) were subjected to drought and cold stress treatments, and such treatments caused enhanced the antioxidant capacity of the extracts (Kirakosyan et al., 2003) In another study, aqueous extract of leaves and unripe fruits of Crataegus aronia was investigated 
for its antioxidant potential which were found to be significant (Ljubuncic et al., 2005). Other species of Crataegus exhibiting antioxidant activity includes $C$. pentaegyna (Ebrahimzadeh \& Bahramian, 2009), $C$. folium \{Hawthorn\} (Demiray et al., 2009).

\section{Anticataract potential}

Cataract is a multifactorial disease primarily associated with oxidative stress produced by free radicals and is the leading cause of blindness worldwide. Both in vitro and in vivo studies were undertaken to investigate the anticataract potential of Crataegus pinnatifida leaves extract. In vitro antioxidant assay of Crataegus pinnatifida leaves extract on NO (nitric oxide) production inhibition, aldose reductase inhibition, and $\mathrm{O}_{2}$ - radical scavenging activities reveals its potential of antioxidant. The in vivo screening investigation of $C$. pinnatifida leaves extract eye drops in $0.1 \%$ hydroxypropyl methyl cellulose solution were prepared to evaluate the anticataract potential. Administration of leaves extract eye drops alternately three times a day in rat pupils with selenite-induced oxidative stress significantly increased serum superoxide dismutase (SOD) and catalase (CAT) activities and tended to reduce malondialdehyde (MDA) level compared with control group. The antioxidant enzymes SOD, CAT, and GSH (glutathione) activities in lens showed a significant increase, thus explains its antioxidant as well as anticataract potential (Wang et al., 2011).

Anti-inflammatory, gastroprotective and antimicrobial activity

Crataegus monogyna, C. oxycantha and $C$. laevigata were shown anti-inflammatory, gastroprotective and antimicrobial activities. Oral administration of extract caused dose-dependent effect in a model of carrageenaninduced rat paw edema and showed anti-inflammatory activity. Extract also produced dose-dependent gastroprotective activity in ethanol-induced acute stress ulcer in rat model. The active components identified in the extract might be responsible for antimicrobial potential of the extract which was investigated against Gram-positive bacteria Micrococcus flavus, Bacillus subtilis, Lysteria monocytogenes and Candida albicans (Tadic et al., 2008). Crataegus tanacetifolia (Lam.) extract had bactericidal effects (Benli et al., 2008).

\section{Antiviral activity}

This activity was investigated on leaves and berries of three Crataegus species including C. aronia var. aronia, C. monogyna as well as C. pseudoheterophylla and was also evaluated for flavonoid amount and total proanthocyanidin content. Results revealed that the extracts containing these active constituents have been verified to be highly effective against Herpes simplex virus (Orhan et al., 2007).

The flavonoids and trimeric procyanidin isolated from Crataegus sinaica demonstrated antiviral activity against HIV. Hyperoside, vitexin, 2"-O-rhamnosylvitexin, (4"'-O-acetyl)-2"-O-rhamnosylvitexin, epicatechin, $(+)$-taxifolin, 3-O- $\beta$-xylopyranosyl-(+)taxifolin may exert their antiviral effects by binding to the protein coat of the virus itself or by inhibiting reverse transcriptase in retroviruses like HIV (Shahat et al., 1998).

\section{Crataegus on reproductive system}

Crataegus cuneata effect on reproductive system was evaluated using medicated serum prepared from its root part. This serum can improve in vitro sperm motility of asthenospermia patients. The sperm specimens of sixteen asthenospermia patients were coincubated with the medicated serum in vitro and sperm motility characteristics were evaluated by computerassisted semen analysis. When compared with the control group, the medicated serum significantly increased the sperm progressive motility in 5 and 15 min and the motility and progressive motility were both increased significantly in 60 and $120 \mathrm{~min}$ (Hu \& Xiong, 2006)

\section{Radioprotective activity}

The fruit of Crataegus microphylla extract when administered intraperitoneally at doses of 25, 50, 100 and $200 \mathrm{mg} / \mathrm{kg}, 1 \mathrm{~h}$ prior to gamma radiation, reduced the frequencies of micro nucleated polychromatic erythrocytes (MnPCE). All four doses of hawthorn extracts significantly reduced the frequencies of $\mathrm{MnPCE}$ and increased the PCE/ $\mathrm{PCE}+\mathrm{NC}$ ratio (polychromatic erythrocytes/polychromatic erythrocytes+normochromatic erythrocytes) in mice bone marrow cells compared with the non drug treated irradiated control group. It appeared that hawthorn extract exhibits antioxidant activity and reduced the genotoxicity induced by gamma radiation in mouse bone marrow cells. Phytochemical study revealed that $C$. microphylla contains high amounts of phenolic compounds, chlorogenic acid, hyperoside and epicatechin which might be responsible for its radioprotective potential (Hosseinimehr et al., 2007).

\section{Immunostimulant activity}

Water-soluble polysaccharide from Crataegus pinnatifida Bge. exhibits immunostimulant activity. Two sub-fractions of this polysaccharide fraction were evaluated on the basis of phagocytosis of macrophage assay, natural killer cells cytotoxicity and spleen lymphocyte proliferation assays. The results showed that 
these polysaccharides significantly induced phagocytic rates and phagocytic indexes by peritoneal macrophages and thus suggested that they should be explored as a novel potential immunostimulants from Crataegus (Li et al., 2009).

\section{Crataegus in anxiety and depression}

A large randomized controlled trial (RCT) found that a combination of Crataegus oxyacantha (hawthorn), Eschscholzia californica (Californian poppy) and magnesium was more effective than placebo in reducing anxiety in 264 individuals with generalised anxiety disorder (Hanus et al., 2004). Another study evaluated for the central effects of the phytotherapeutic product-CPV (dry extract of Crataegus oxyacantha, Passiflora incarnata and Valeriana officinalis) in animals models. Evaluation of anxiolytic effect of this extract on the elevated plusmaze (EPM) was carried out in order to investigate the psychopharmacological profile of CPV extract. CPV extract (430 and $860 \mathrm{mg} / \mathrm{kg}$ ) presented an anxiolytic effect on rats (increased the number of entries into the open arms in the EPM) and, furthermore, a tendency of slight amnesic effect for the doses (430 and $860 \mathrm{mg} / \mathrm{kg}$ ), but less intense when compared to diazepam $(1.5 \mathrm{mg} / \mathrm{kg})$, (Min et al., 2000; Tabach et al., 2009).

\section{Diuretic/ACE inhibitor activity}

A study had been done to check this activity experimentally which involves the use of a homeopathic Crataegus preparation Cralonin. In this study the efficacy of the homeopathic Crataegus preparation for non-inferiority to standard treatment for mild cardiac insufficiency was compared. Multicentre non-randomised cohort study was conducted in patients aged 50-75 years in New York Heart Association class II. Patients received Cralonin ( $n s 110)$ or ACE inhibitor diuretics ( $n s 102)$ for eight weeks. To adjust for confounding by baseline factors, populations were stratified according to propensity score. After adjusting, there were no statistically significant differences between treatment groups. The Crataegus-based preparation Cralonin is non-inferior to usual ACE inhibitor diuretics treatment for mild cardiac insufficiency on all parameters except BP reduction (Schroder et al., 2003).

\section{Hypoglycaemic activity}

Diabetes mellitus is a syndrome which affects more and more people in all countries over the world. Crataegus containing herbal extracts were used widely to treat this condiction in Mexico. Such treatment may be of considerable benefit especially during the early stages of the illness. Crataegus mexicana Moc., C. pubescens, and C. presl root infusion containing active constituents like tannins and flavonoids may act as antidiabetic (AndradeCetto \& Heinrich, 2005). In another study the effects of a decoction prepared from the leaves and unripe fruits of Crataegus aronia, in streptozotocin-induced diabetic rats, were conducted and its effect on plasma and tissue indices of oxidative stress, as well as blood glucose levels was measured. This study concluded that decoction prepared from the leaves and unripe fruits of $C$. aronia normalizes plasma lipid peroxide levels and lowers blood glucose levels in diabetic (Ljubuncic et al., 2006).

\section{Hepatoprotective activity}

Crataegus pinnatifida was investigated for hepatoprotective activity and the results suggested that this plant has anti-inflammatory potential which play a role in hepatoprotection (Kao et al., 2005).

\section{Cytotoxic activity}

Cytotoxic ursane-type triterpenes were isolated from Crataegus pinnatifida which were identified as uvaol, ursolic acid and 3-oxo-ursolic acid. The cytotoxic activities of these compounds were tested in vitro against murine L1210 and human cancer cell lines (A549, SKOV-3, SK-MEL-2, XF498, and HCT15). Uvaol and ursolic acid showed moderate cytotoxicities against L1210, whereas they showed weak activities against human cancer cell lines. However, 3-oxo-ursolic acid exhibited potent cytotoxic activities both in murine and in human cancer cell lines (Min et al., 2000). Another study to clarify the active components in anti-transformation and anti-tumor promotion, involved the collection of the polyphenol fraction (CF-TP) of hot-water extracts from dried fruits of $C$. pinnatifida and different assays were conducted using this fraction such as anchorageindependent transformation assay. CF-TP significantly inhibited 12-O-tetradecanoylphorbol-13-acetate (TPA)induced cell transformation in $\mathrm{JB} 6 \mathrm{P}^{+}$cells. The results indicated that CF-TP significantly inhibited the generation of reactive oxygen species (ROS) and the phenomena of inflammation induced by TPA. It also suppressed the expression of COX-2 and iNOS, and the activation of ornithine decarboxylase (ODC). Furthermore, CF-TP inhibited benzo[ $\alpha]$ pyrene $(\mathrm{B}[\alpha] \mathrm{P}) / \mathrm{TPA}$-induced skin tumor formation and decreased the incidence of tumor. The results revealed that CF-TP possesses potential as a cancer chemopreventive agent against tumor promotion (Kao et al., 2007).

\section{Miscellaneous}

Crataegus species have number of various biological as well as pharmacological activities as shown in Table 1. 
Dosage

Dosages of Crataegus extracts vary, depending upon concentration of extract. Therapeutic dose of an extract standardized to contain 1.8 percent vitexin-4rhamnoside is $100-250 \mathrm{mg}$ three times daily. A standardized extract containing $18 \%$ oligomeric procyanidins id dosed in the range of 250-500 mg daily (Monograph, 2010).

\section{Toxicology}

Crataegus has been shown to have low toxicity with an LD50 of $25 \mathrm{mg} / \mathrm{kg}$ (Ammon \& Handel, 1981a). Commission $\mathrm{E}$ monograph states that mice and rats have been safely given a standardized extract at doses up to 3 $\mathrm{g} / \mathrm{kg}$ body weight (Blumenthal et al., 1988). Studies in rats using excessive dosing of hawthorn flower extract (600 mg/kg/day; flavonoids) over 30 days showed unremarkable adverse events. In humans the acute oral toxicity of hawthorn was $6 \mathrm{~g} / \mathrm{kg}$.

\section{Contraindications}

It is generally considered safe; however relative contraindications exist with cases of hypersensitivity or a history of an allergic reaction to Crataegus or any of its components. An absolute contraindication has been suggested in children under the age of 12 (Weikl et al., 1996; Ammon \& Handel, 1981b).

\section{Side effects}

Hawthorn was well tolerated in studies lasting up to sixteen weeks. Some side effects, while rare, may have been related to hawthorn extracts cited in the literature are: mild rash, headache, sweating, dizziness, sleepiness, agitation, gastrointestinal complaints (Houser, 2006).

\section{Drug interactions}

The flavonoid components of hawthorn may be responsible for hawthorn's beneficial effects in the treatment of heart failure. However, these components may also affect P-glycoprotein function and cause interactions with drugs that are P-glycoprotein substrates, such as digoxin, which is also used to treat heart failure (Tankanow et al., 2003).

\section{Preparations}

Tincture, decoction and powder.

\section{Products}

Tincture, capsule, tablet, bulk herb and syrup
(Tankanow et al., 2003).

\section{Clinical trials of hawthorn (Crataegus)}

Clinical trials are a means of developing new treatments and medications for diseases and conditions. Clinical trials are conducted to allow safety and efficacy data to be collected for health interventions (e.g., drugs, diagnostics, devices, therapy protocols). Clinical trial reviewed in this paper have been inconsistent in terms of criteria used (sample size, preparation and dosage, trial period, assessment method) but have been largely consistent with regards to positive outcome results. Adverse effect relating to the use of hawthorn preparations are infrequent and mild, even at higher dosage ranges but a retrospective study has suggested a negative results of the long term use of hawthorn in the prognosis of heart failure (Tassell et al., 2010; Zick et al., 2008). Clinical studies on hawthorn (Crataegus) preparations have been shown in Table 3.

\section{Regulatory status for hawthorn in selected countries}

Regulatory Affairs, also called Government Affairs, is a profession within regulated industries, such as pharmaceuticals, medical devices, energy, and banking. Regulatory Affairs also has a very specific meaning within the healthcare industries (pharmaceuticals, medical devices, Biologics and functional foods) (Houser, 2006) Chart 3

Worldwide used species of Crataegus as herbal drug or drug material

More than twenty species of hawthorn are used as herbal drugs or drug materials in the world. Some of them are officially listed in the pharmacopoeias of many countries such as China, Germany, France and England (Chang et al., 2002) Chart 4.

\section{Conclusion}

The medicinal properties of Crataegus species, Rosaceae, as discussed in this review paper highlighted significant pharmacological activities of this species. Pharmacological actions experimented on animals or in vitro models conclude its potential as cardioactive, hypotensive, hypolipidaemic, gastroprotective, hepatoprotective, antivirus, including anti-hiv, antioxidant, immunostimulant, antidiabetic, cytotoxic etc. Presence of bioflavanoids like oligomeric procyanidins, triterpenes, polysaccharides and other active compounds might be responsible for these pharmacological activities. It is believed that detailed information as presented in this review on its various biological properties, chemistry 


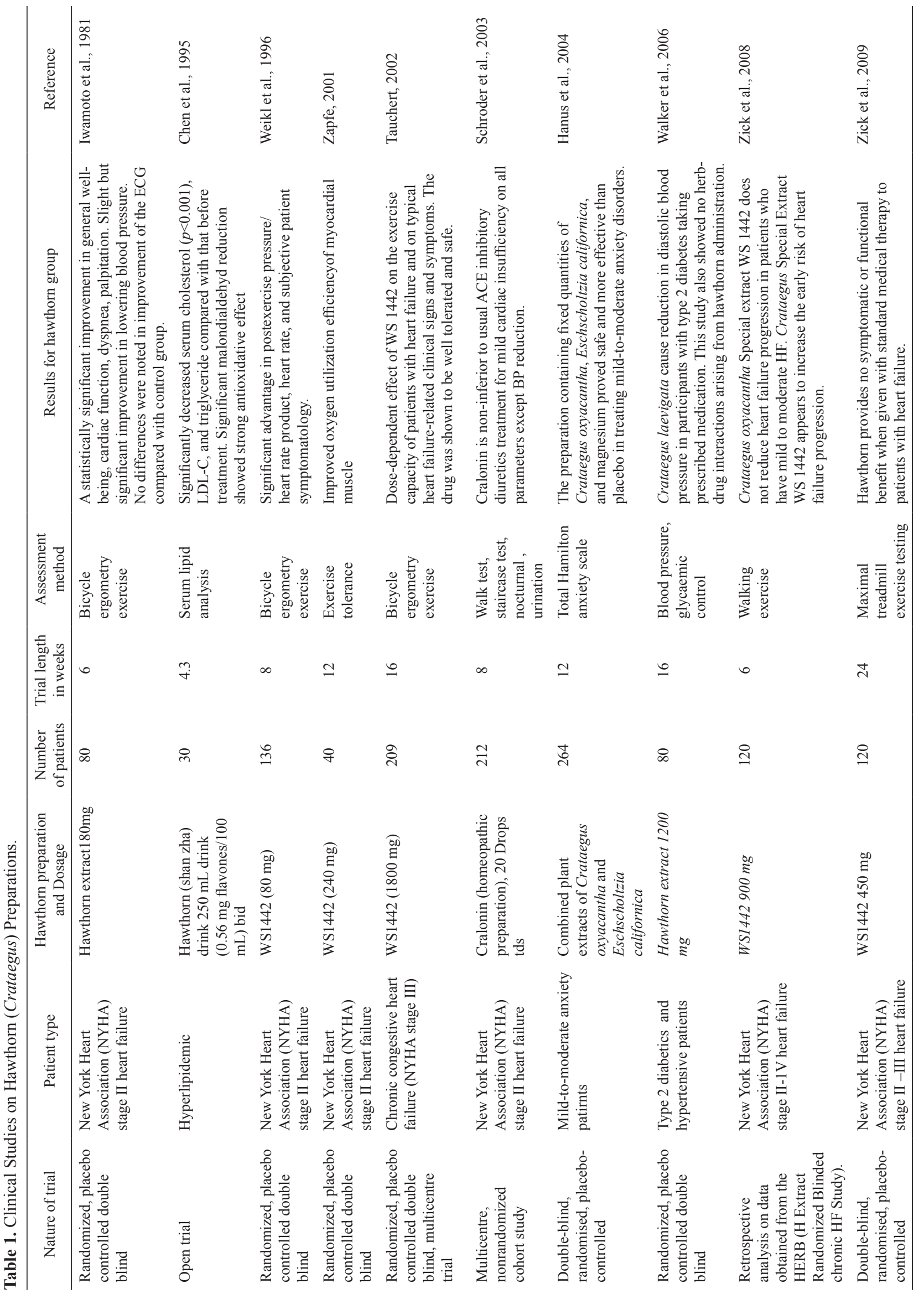


Chart 3. Regulatory status of Crataegus.

\begin{tabular}{|ll|}
\hline \multicolumn{1}{|c|}{ Country name } & \multicolumn{1}{c|}{ Regulatory status } \\
\hline Australia & Hawthorn is not included in Part 4 of Schedule 4 of the Therapeutic Goods Regulation. \\
US & $\begin{array}{l}\text { Hawthorn flower and leaf is official in United States Pharmacopeia. National Formulary (USP26. NF 21, 2003). Hawthorn } \\
\text { does not have generally recognised as safe (GRAS) status, however it is freely available as dietary supplement in the US under } \\
\text { DSHEA legislation (Dietary Supplement Health and Education Act of 1994). }\end{array}$ \\
UK and Germany & $\begin{array}{l}\text { Hawthorn berry, flower and leaf are each individually covered by a negative assessment. Hawthorn is not included in General } \\
\text { Sale List. Hawthorn leaf and flower combined are covered by a positive Commission E Monograph. Hawthorn berries and } \\
\text { hawthorn leaf and flower are official in European Pharmacopeia 4.3. }\end{array}$ \\
\hline
\end{tabular}

Chart 4. Worldwide acceptance of Crataegus species.

\begin{tabular}{|c|c|c|}
\hline Pharmacopoeias & Species accepted & Parts used \\
\hline British Pharmacopoeia (2000) & C. oxyacantha L., C. monogyna Jacq. & Fruits, leaves, and flowers \\
\hline European Pharmacopoeia (1998) & C. oxyacantha L., C. monogyna Jacq. & Fruits, flowers \\
\hline Chinese Pharmacopoeia (English ed., 1997) & C. pinnatifida Bge., C. pinnatifida Bge. var. major N.E. Br. & Fruits \\
\hline France Pharmacopoeia (1998) & C. oxyacantha L., C. monogyna Jacq. & Fruits \\
\hline $\begin{array}{l}\text { German Pharmacopoeia (DAB, 1997) and Swiss } \\
\text { Pharmacopoeia (1997) }\end{array}$ & $\begin{array}{l}\text { C. oxyacantha L., C. monogyna Jacq., C. pentagyna Waldst. } C \text {. } \\
\text { nigra Waldst., C. azarolus L. }\end{array}$ & Leaves with flowers \\
\hline
\end{tabular}

of compounds, clinical trials and regulatory status of Crataegus might provide incentive for proper evaluation of the use of its various species in medicine. Last but not the least, this review emphasizes the potential genus Crataegus to be employed in new therapeutic drugs and provide the basis for future research on the various species of this genus.

\section{References}

Ahmed AA, Khattab AM, Grace MH, Sahl MM 2001. A new eudesmanolide from Crataegus flava fruits. Fitoterapia 72: 756-759.

Amanzadeh Y, Khanavi M, Khatamsaz M, Rajabi A, Ebrahimi SES 2007. High performance thin-layer chromatographic fingerprints of flavonoids and phenol carboxylic acids for standardization of Iranian species of the genus Crataegus L. Iranian J Pharm Sci 3: 143-152.

Ammon HPT, Handel M 1981a. Crataegus, toxicology and pharmacology, Part 1: toxicity Planta Med 43: 105-120.

Ammon HPT, Handel M 1981b. Crataegus, toxicology and pharmacology, Part III: Planta Med 43: 313-322.

Andrade-Cetto A, Heinrich M 2005. Mexican plants with hypoglycaemic effect used in the treatment of diabetes. $J$ Ethnopharmacol 99: 325-348.

Aneta W, Oszmianski J 2007. Influence of polyphenols isolated from Scutellaria baicalensis Georgi and Crataegus oxyacantha on the oxidative stability of cholesterol in butter stored in various conditions. Eur Food Res Technol 224: 635-642.

Anna S, Oszmian J, Aneta W 2007. Antioxidant activity of phenolic compounds of Hawthorn, pine, skullcap. Food Chemistry 103: 853-859.

Arrieta J, Siles-Barrios D, García-Sanchez J, Reyes-Trejo B, Sanchez-Mendoza M 2010. Relaxant effect of the extracts of Crataegus mexicana on guinea pig tracheal smooth muscle. Pharmacogn J 2: 40-46.

Arslan R, Bor Z, Bektas N, Mericli A H, Ozturk Y 2011. Antithrombotic effects of ethanol extract of Crataegus orientalis in the carrageenan-induced mice tail thrombosis model. Thromb Res 127: 210-213.

Bahorun T, Aumjaud E, Ramphul H, Rycha M, Luximon-Ramma A, Trotin F, Aruoma OI 2003. Phenolic constituents and antioxidant capacities of Crataegus monogyna (Hawthorn) callus extracts. Nahrung 47: 191-198.

Bahri-Sahloul R, Ammar S, Fredj RB, Saguem S, Gree S, Trotin F, Skhiri FH 2009. Polyphenol contents and antioxidant activities of extracts from flowers of two Crataegus azarolus L. varieties. Pakistan J Biol Sci 12: 660-668.

Batyuk VS 1966. Structure of the flavonoids of Crataegus curvisepala. Chem Nat Compd 2: 233-234.

Belz GG, Butzer R, Gaus W, Loew D 2002. Camphor-Crataegus berry extract combination dose-dependently reduces tilt induced fall in blood pressure in orthostatic hypotension. Phytomedicine 9: 581-588.

Benli M, Yig N, Geven F, Kerim G, Bingo U 2008. Antimicrobial activity of endemic Crataegus tanacetifolia (Lam.) Pers and observation of the inhibition effect on bacterial cells. Cell Biochem Funct 26: 844-851.

Bersin T, Muller A, Schwarz H 1955. Ingredients of Crataegus oxyacantha L. III. Heptahydroxyflavan glycoside. Arzneimittelforschung 5: 490-491.

Blesken R 1992. Crataegus in cardiology. Fortschr Med 15: 290-292.

Blumenthal M, Busse W, Goldberg A 1988. The complete Germen commission E Monographs, Boston MA: American Botanical Council, p. 142-144.

Bykov VI, Glyzin VI 1972. Flavonoids of the genus Crataegus. Chem Nat Compd 8: 672-673.

Chang Q, Zuo Z, Harrison F, Chow MS 2002. Hawthorn. J Clin 
Pharmacol 42: 605-612.

Chen JD, Wu YZ, Tao ZL, Chen ZM, Liu XP 1995. Hawthorn (shan zha) drink and its lowering effect on blood lipid levels in humans and rats. World Rev Nutr Diet 77: 14754.

Chen J, Song S, He J, Xu S 2008. A study of the chemical constituents of the leaves of Crataegus pinnatifida. Asian J Trad Med 3: 80-83.

Degenring FH, Suter A, Weber M, Saller R 2003. A randomised double blind placebo controlled clinical trial of a standardised extract of fresh Crataegus berries $\left(\right.$ Crataegisan $\left.^{\circledR}\right)$ in the treatment of patients with congestive heart failure NYHA II. Phytomedicine 10: 363-369.

Demiray S, Pintado ME, Castro PML 2009. Evaluation of phenolic profiles and antioxidant activities of Turkish medicinal plants: Tilia argentea, Crataegi folium leaves and Polygonum bistorta roots. World Acad Sci Eng Technol 54: 312-317.

Donmez AA 2004. The genus Crataegus L. (Rosaceae) with special reference to hybridisation and biodiversity in Turkey. Turk J Bot 28: 29-37.

Ebrahimzadeh MA, Bahramian F 2009. Antioxidant activity of Crataegus pentaegyna fruit extract used as traditional medicine in Iran. Pakistan J Biol Sci 12: 413-419.

Furst R, Zirrgiebel U, Totzke F, Zahler S, Vollmar AM, Koch E 2010. The Crataegus extract WS 1442 inhibits balloon catheter-induced intimal hyperplasia in the rat carotid artery by directly influencing PDGFR-beta. Atherosclerosis 2: 409-417.

Garjani A, Nazemiyeh H, Maleki N, Valizadeh H 2000. Effects of extracts from flowering tops of Crataegus meyeri A. Pojark. on ischaemic arrhythmias in anaesthetized rats. Phytother Res 14: 428-431.

Gazizov FY, Glushenkova AI 1996. Phospholipids of the pericarp of Crataegus turkestanica. Chem Nat Compd 31: 465-466.

Guven K, Yucel E, Cetintas F 2006. Antimicrobial activities of fruits of Crataegus and Pyrus. Species. Pharm Biol 44: 79-83.

Hanus M, Lafon J, Mathieu M 2004. Double-blind, randomised, placebo-controlled study to evaluate the efficacy and safety of a fixed combination containing two plant extracts (Crataegus oxyacantha and Eschscholtzia californica) and magnesium in mild-to-moderate anxiety disorders. Curr Med Res Opin 20: 63-71.

Horvat RJ, Chapman GW 2007. Identification of volatile compounds from ripe Mayhaw fruit (Crataegus opaca, C. aestzvalzs, and C. rufula. J Food Quality 14: 307312 .

Hosseinimehr SJ, Azadbakht M, Mousavi SM, Mahmoudzadeh A, Akhlaghpoor S 2007. Radioprotective effects of hawthorn fruit extract against gamma irriradiation in mouse bone marrow cells. J Radiat Res 48: 63-67.

Houser D 2006. Supplement spotlight: Hawthorn.

Hu L, Xiong CL 2006. The influence of medicated serum with root of Crataegus cuneata on human sperm motility parameters in vitro. China J Chinese Materia Med 4: 333-335.

Huang Y, Chen ZY, Ho WKK 2004. Crataegus (Howthorn). In: Lester P, Choon NO, Barry H, Herbal and traditional medicine, biomolecular and clinical aspects. China 21 CRC Press DOI: 10.1201/9780203025901.ch21.

Ikeda T, Ogawa Y, Nohara T 1999. A new triterpenoid from Crataegus cuneata, Chem Pharm Bull 47: 1487-1488.

Iwamoto M, Sato T, Ishizaki T 1981. The clinical effect of Crataegutt in heart disease of ischemic or hypertensive origin. A multicenter double-blind study. Planta Med 42: 1-16.

Jayalakshmi R, Thirupurasundari CJ, Niranjali DS 2006. Pretreatment with alcoholic extract of Crataegus oxycantha (AEC) activates mitochondrial protection during isoproterenol -induced myocardial infarction in rats. Mol Cell Biochem 292: 59-67.

$\mathrm{Ju}$ LY 2005. Crataegus oxyacantha (aubepine) in the use as herb medicine in France. Zhongguo Zhong Yao Za Zhi 30: 634-40.

Kao ES, Wang CJ, Lin WL, Chu CY, Tseng TH 2007. Effects of polyphenols derived from fruit of Crataegus pinnatifida on cell transformation, dermal edema and skin tumor formation by phorbol ester application. Food Chem Toxicol 45: 1795-1804.

Kao ES, Wang CJ, Lin WG, Yin YF, Wang CP, Tseng TH 2005. Anti-inflammatory potential of flavonoid contents from dried fruit of Crataegus pinnatifida in vitro and in vivo. $J$ Agric Food Chem 53: 430-436.

Kashnikova MV 1984. Flavonoids of the flowers of Crataegus sanguinea. Chem Nat Compd 20: 105-106.

Kashnikova M V, Sheichenko V I, Gluzin VI, Samylina I A 1984. Acetylvitexin - a new flavonoid from the flowers of Crataegus sanguinea. Chem Nat Compd 20: 106.

Khalil R, Abuharfeil N, Shabsoug B 2008. The effect of Crataegus aronica aqueous extract in rabbits fed with high cholesterol diet. Eur J Sci Res 22: 352-360.

Kirakosyan A, Seymour E, Kaufman BP, Warber S, Bolling S, Chang CS 2003. Antioxidant capacity of polyphenolic extracts from leaves of Crataegus laevigata and Crataegus monogyna (Hawthorn) subjected to drought and cold stress. J Agr Food Chem 51: 3973-3976.

Kocyildiz ZC, Birman H, Olgac V, Akgun-Dar K, Meliko G, Mericli AH 2006. Crataegus tanacetifolia leaf extract prevents L-NAME-induced hypertension in rats: a morphological study. Phytother Res 20: 6-70.

Kovaleva AM, Goncharov NF, Komissarenko AN 2009. GC/ MS study of essential oil components from flowers of Crataegus jackii, C. robesoniana, and C. flabellate. Chem Nat Compd 45: 582-584.

Kuliev VB, Poletaeva LV 1983. Polysaccharides of Crataegus. II. Polysaccharides of the fruit of Crataegus meyeri. Chem Nat Compd 18: 612-613.

Kuliev VB, Poletaeva, LV 1984. Polysaccharides of Crataegus 
II. Polysaccharides of the fruit of Crataegus meyeri. Chem Nat Compd 20: 100-101.

Li F, Yuan Q, Rashid F 2009. Isolation, purification and immunobiological activity of a new water-soluble bee pollen polysaccharide from Crataegus pinnatifida Bge. Carbohyd Polym 78: 80-88.

Lin Y, Vermeer MA Trautwein EA 2009. Triterpenic acids present in hawthorn lower plasma cholesterol by inhibiting intestinal ACAT activity in hamsters. eCAM 1-9: doi:10.1093/ecam/nep007.

Liu P, Kallio H, Lu D, Zhou C, Ou S, Yang B 2010. Acids, sugars, and sugar alcohols in chinese hawthorn (Crataegus spp.) fruits. J Agric Food Chem 58: 1012-1019.

Ljubuncic P, Azaizeh H, Cogan U, Bomzon A 2006. The effects of a decoction prepared from the leaves and unripe fruits of Crataegus aronia in streptozotocininduced diabetic rats. $J$ Complement Med 3: 6. doi: 10.2202/1553-3840.1027.

Ljubuncic P, Portnaya I, Cogan U, Azaizeh H, Bomzon A 2005. Antioxidant activity of Crataegus aronia aqueous extract used in traditional Arab medicine in Israel. $J$ Ethnopharmacol 101: 153-161.

Long SR, Carey RA, Crofoot KM, Proteau PJ, Filtz T M 2006. Effect of hawthorn (Crataegus oxycantha) crude extract and chromatographic fractions on multiple activities in a cultured cardiomyocyte assay. Phytomedicine 13: 643-650.

Maharik N, Elgengaihi S, Taha H 2009. Anthocyanin production in callus cultures of Crataegus sinaica boiss. Int J Acad Res 1: 30-34.

Maurya R, Yadav PP 2005. Furanoflavonoids: An overview. Nat Prod Rep 22: 400-424.

Melikoglu G, Bitis L, Mericli AH 2004. Flavonoids of Crataegus microphylla. Nat Prod Res 18: 211-213.

Miller AL 1998. Botanical influences on cardiovascular disease. Altern Med Rev 3: 422-431.

Min BS, Kim YH, Lee SM, Jung HJ, Lee JS, Na MK, Lee CO, Lee JP, Bae K 2000. Cytotoxic triterpenes from Crataegus pinnatifida. Arch Pharm Res 23: 155-158.

Monographs 2010. Crataegus oxyacantha Hawthorn Monograph. Altern Med Rev 15: 164-167.

Nikolov NT, Vodenicharov RI 2003. Di-C-glycosides from Crataegus monogyna. Chem Nat Compd 11: 436-437.

Orhan I, Ozcelik B, Kartal M, Ozdeveci B, Duman H 2007. HPLC Quantification of vitexine-2-O-rhamnoside and hyperoside in three Crataegus species and their antimicrobial and antiviral activities. Chromatographia 66: S153-S157.

Petkov V 1979. Plants and hypotensive, antiatheromatous and coronarodilatating action. Am J Chinese Med 3: 197236.

Rayyan S, Fossen T, Nateland HS, Andersen OM 2005. Isolation and identification of flavonoids, including flavone rotamers, from the herbal drug 'Crataegi folium cum flore' (hawthorn). Phytochem Anal 16: 334-41.
Rewerski W, Lewak S 1967. Some pharmacological properties of flavan polymers isolated from hawthorn (Crataegus oxyacantha). Arzneimittelforschung 17: 490-491.

Rigelsky JM, Sweet BV 2002. Hawthorn: Pharmacology and therapeutic uses. Am J Health Syst Pharm 59: 417-422.

Ringl A, Prinz S, Huefner A, Kurzmann M, Kopp B 2007. Chemosystematic value of flavonoids from Crataegus $x$ macrocarpa (Rosaceae) with special emphasis on $(R)$ and $(S)$-eriodictyol-7-O-glucuronide and luteolin-7- $O$ glucuronide. Chem Biodivers 4: 154-162.

Robertson KR 1974. The genera of Rosaceae in the southeastern United States. J Arnold Arboretum 55: 303B-332, 334B-401, 611B-662.

Schroder D, Weiser M, Klein P 2003. Efficacy of a homeopathic Crataegus preparation compared with usual therapy for mild (NYHA II) cardiac insufficiency: results of an observational cohort study. Eur J Heart Fail 5: 319-26.

Shahat AA, Hammouda F, Ismail SI, Azzam SA, De Bruyne T, Lasure A, Van Poel B, Pieters L, Vlietinck AJ 1996. Anti-complementary activity of Crataegus sinaica. Planta Med 62: 10-13.

Shahat A, Ismail S, Hammouda F 1998. Anti-HIV activity of flavonoids and proanthocyanidins from Crataegus sinaica. Phytomedicine 2: 133-136.

Sozer U, Donmez AA, Mericli AH 2006. Constituents from the leaves of Crataegus davisii Browicz. Sci Pharm 74: 203-208.

Svedstrom U, Vuorela H, Kostiainen R, Tuominen J, Kokkonen J, Rauha JP, Laakso I, Hiltunen R 2002. Isolation and identification of oligomeric procyanidins from Crataegus leaves and flowers. Phytochemistry 60: 821825.

Tabach R, Mattei R, Carlini EL 2009. Pharmacological evaluation of a phytotherapeutic product - CPV (dry extract of Crataegus oxyacantha L., Passiflora incarnata L. and Valeriana officinalis L.) in laboratory animals. Rev Bras Farmacogn 19: 255-260.

Tadic VM, Dobric S, Markovic GM, Sofija M, Tanja S 2008. Anti-inflammatory, gastroprotective, free-radicalscavenging and antimicrobial activities of hawthorn berries ethanol extract. J Agr Food Chem 56: 77007709.

Tankanow R, Tamer HR, Streetman DS, Smith SG, Welton JL, Annesley T, Aaronson KD, Bleske BE 2003. Interaction study between digoxin and a preparation of hawthorn (Crataegus oxyacantha). J Clin Pharmacol 43: 637642.

Tassell MC, Kingston R, Gilroy D, Lehane M, Furey A 2010. Hawthorn (Crataegus spp.) in the treatment of cardiovascular disease. Pharmacogn Rev 4: 32-41.

Tauchert M 2002. Efficacy and safety of Crataegus extract WS 1442 in comparison with placebo in patients with chronic stable New York Heart Association class-III heart failure. Am Heart J 143: 910-915.

Verma SK, Jain V, Verma D, Khamesra R 2007. Crataegus 
oxyacantha- A cardioprotective herb. J Herbal Med Toxicol 1: 65-71.

Vivar-Vera MA, Salazar-Montoya JA, Calva-Calva G, RamosRamirez EG 2007. Extraction, thermal stability and kinetic behavior of pectinmethylesterase from hawthorn (Crataegus pubescens) fruit. Food Sci Technol 40: 278284.

Wagner H, Grevel J 1982. Cardioactive drugs IV. Planta Med 6: 98-101.

Walker AF, Marakis G, Simpson E, Hope JL, Robinson PA, Hassanein M, Simpson HCR 2006. Hypotensive effects of hawthorn for patients with diabetes taking prescription drugs. Brit J Gen Prac 437-443.

Wang T, Zhang P, Zhao C, Zhang Y, Liu H, Hu L, Gao X, Zhang D 2011. Prevention effect in selenite-induced cataract in vivo and antioxidative effects in vitro of Crataegus pinnatifida leaves. Biol Trace Elem Res 142: 106-116.

Weikl A, Assmus KD, Neukum-Schmidt A, Schmitz J, Zapfe G, Noh HS, Siegrist J 1996. Crataegus special extract WS 1442. Assessment of objective effectiveness in patients with heart failure (NYHA II). Fortschr Med 114: 291296.

WHO, 2003. Monographs on medicinal plants newly independent states, p. 91-93.

Zapfe G 2001. Clinical efficacy of Crataegus extracts WS ${ }^{\circledR}$ 1442 in congestive heart failure NYHA class II.
Phytomedicine 8: 262-266.

Zhang PC, Xu XU 2001. Flavonoid ketohexosefuranosides from the leaves of Crataegus pinnatifida Bge. var. major N.E.Br. Phytochemistry 57: 1249-1253.

Zhang PC, Zhou YJ, Xu SX 2000. Two novel flavonoid glycosides from Crataegus pinnatifida Bge.var. major N.E.Br. J Asian Nat Prod Res 3: 77-82.

Zick SM, Gillespie B, Aaronson KD 2008. The effect of Crataegus oxycantha special extract WSS 1442 on clinical progression in patients with mild to moderate symptoms of heart failure. Eur J Heart Fail 10: 587593.

Zick SM, Gillespie B, Aaronson KD, Vautaw BM 2009. Hawthorn extract randomized blinded chronic heart failure (HERB CHF) trial. Eur J Heart Fail 11: 990999.

\section{*Correspondence}

\section{Dinesh Kumar}

Department of Pharmaceutical Sciences, University of Kashmir

190006, J\&K, India

zabhat@kashmiruniversity.ac.in

Tel.: +91 9419214116, + 919882120308 